\title{
SRM Activities \\ Nebraska Section of the Society of Range Management Hosts Summer Tour and Dedicates Memorial Wall to Don Cox
}

\author{
By Judy Lanka, Michael Croxen, Patti Barney, Mary Reece, \\ Kristin Miller, and Tim Griffin
}

The Nebraska Section of the Society of Range Management (NE SRM) hosted a summer range tour of the Nebraska National Forest, Bessey Ranger District, near Halsey, Nebraska, on July 19, 2004. This was the first time in a number of years that a summer tour was held. Nearly 40 SRM members and ranchers were in attendance.

The main focus of the forest tour was to look at the thinning and prescribed burning that has been done over the last 2 years on the Bessey Ranger District. This forest was completely hand planted in the Nebraska Sandhills. The initial planting was done in 1902 when the area was designated the Dismal River Reserve. This forest reserve was designated a national forest in 1907.

Many of the trees that were planted were experimental species from the tree nursery located there. Most of the trees were planted under the Franklin Delano Roosevelt administration from 1934 to 1942. The plantings were done by the Civilian Conservation Corps. The district is named for $\mathrm{Dr}$ Charles Bessey, a botanist with the University of Nebraska.

The Bessey Ranger District encompasses just over 91,000 acres; of this, 30,000 acres were originally planted to tree cover, and the remainder was left as open rangeland. The Plum Fire, a catastrophic wildfire that occurred in 1965, destroyed approximately one-third of the original acres of trees. Now, approximately 22,000 acres of mostly ponderosa pine, jack pine, and Eastern Red Cedar, remain. Over the years, there has been a significant encroachment of

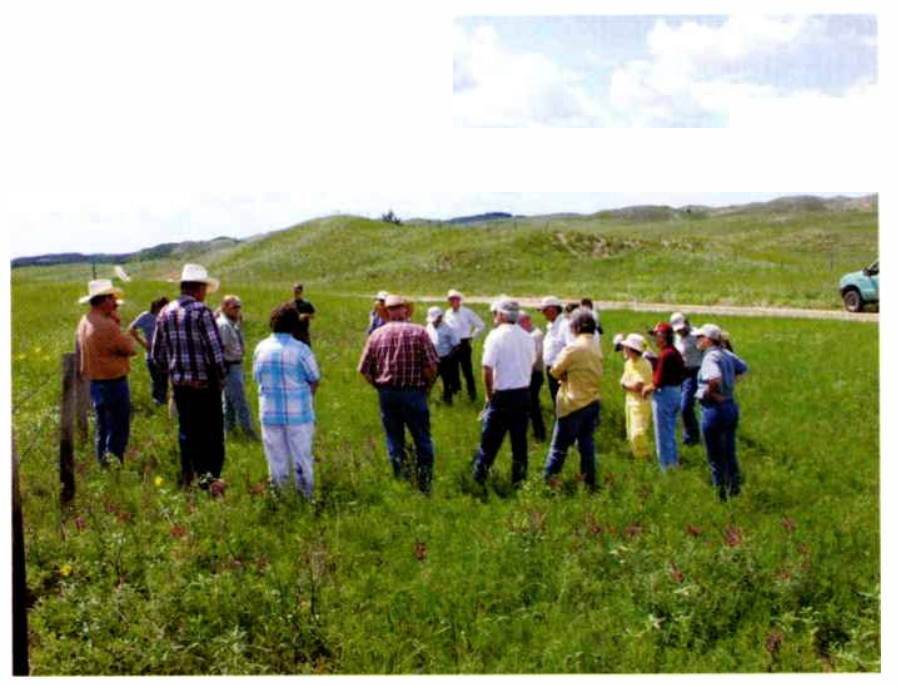

Figure 1. Tour participants in an area that was prescribed burned on March 18, 2004. Plant diversity and vigor is high in this area. The area across the road has not had a burn.

Eastern Red Cedar in both the open rangeland and within the planted areas.

The thinning project on the Bessey Unit began in 2003. The primary goal for the thinning project was to reduce the possibility of a catastrophic wildfire in the planted forest areas. The thinning projects are part of President Bush's Healthy Forest Initiative dealing with old, crowded stands and diseased timber and to address the possibilities of catastrophic wildfires near communities. The State Historic Preservation Office considers the forested area to be of historical significance and because of its uniqueness, and previously mentioned reasons, the district is trying to maintain and enhance the health of the forest. 
Eight hundred twenty-two acres of Eastern Red Cedar and ponderosa pine were mechanically thinned to 18 feet between Eastern Red Cedar and 16 feet between ponderosa pine in the first year of the project. The thinned trees were piled for burning at a later time when there is adequate snow cover. A small area near the camping sites and administrative area was thinned by a method called "lop and scatter" rather than piling the trees. Because of the long distance from the forest to a saw mill, the thinned tree disposal was done either by burning the piles, or by allowing campers and other forest users to purchase the "lop and scatter" trees for post and poles or for firewood. The long-term management plan for these areas is to follow up with prescribed fire in the understory to remove any encroaching seedlings.

The 2004 thinning has and will occur in two areas. The first area that was thinned was 250 acres of Eastern Red Cedar within a 1,036-acre area that had prescribed burns done on March 18 and 30, 2004. The second area to be thinned will be primarily in a ponderosa pine stand and will cover 963 acres. Trees in this area will be thinned at a wider distance between trees: 24 feet for Eastern Red Cedar and 18 feet for ponderosa pine. After the 2003 thinning was completed, the Forest Service was concerned that there was not enough distance between trees, which could allow for a crown fire to carry more easily.

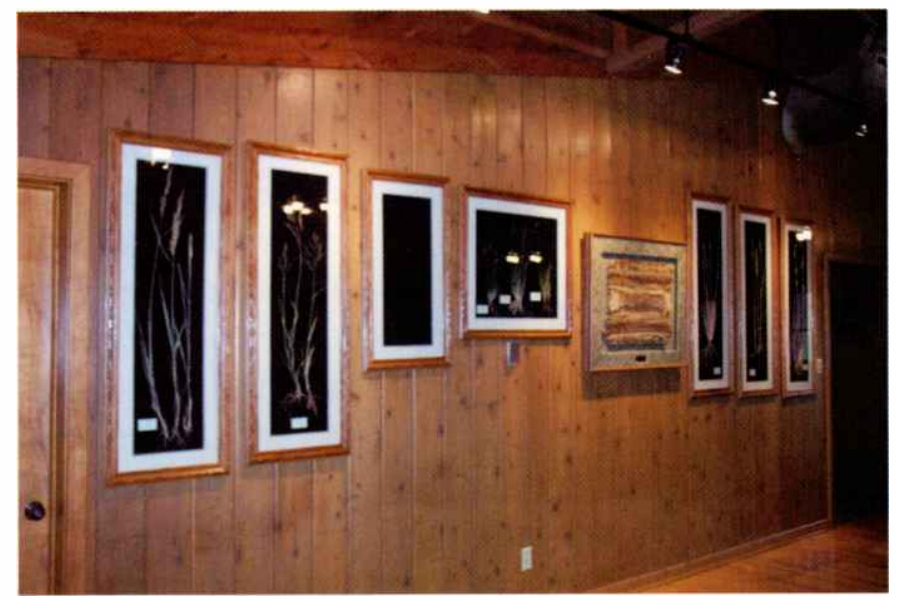

Figure 2. Don Cox Memorial Wall. The plant mounts and framing were done by Dave George of Rushville, Nebraska. The center of the display is a native grass weaving done by Don Cox.
The tour also focused on prescribed burning done on the open rangeland in the forest. The Bessey Ranger District has completed several spring burns over the last 5 years on approximately 1,600 acres (Figure 1). The primary goal for these burns is to control the spread of Eastern Red Cedar less than 3 feet tall. Other benefits to the prescribed burning besides cedar control include improved habitat for the prairie chicken and the sharptail grouse, improved nutritional levels of the grasses and forbs, and improved range condition and plant diversity.

Following the forest tour, the participants got their first look at the Don Cox Memorial Grass Display (Figure 2). This display is located in the ballroom of the Nebraska State 4-H Camp lodge in Halsey, Nebraska. This display is a cooperative effort of NE SRM and the State 4-H Camp.

The camp is located at a site provided through a long-term special use permit with the Bessey Unit of the Nebraska National Forest. The State 4-H Camp requested SRM members involved with the Nebraska Range Youth Camp, who uses the camp for one week in June annually, to assist with developing an educational display utilizing the native grasses located in the Nebraska Sandhills. The committee worked for nearly a year to make this display possible.

The Grass Display was completed primarily by Dave George (both NE and SD sections member), Rangeland Management Specialist for Natural Resources Conservation Service in northwest Nebraska. He pressed the native grasses, built the frames, and matted the impressive displays. The grasses chosen for the display include sand bluestem, prairie sand-reed, little bluestem, hairy grama, blue grama, sun sedge, sand lovegrass, switchgrass, and indiangrass. The focal point of the display, however, is a framed weaving of native grasses created by Don Cox.

Don Cox, a longtime Nebraska Sandhills rancher who died in 2000, was born in Calf Creek Valley, Nebraska, north of Mullen in 1912. He and his wife, Donna, raised Hereford cattle and Don had a keen interest in rangeland. He shared his interest and knowledge with young and old alike.

He joined the American Society for Range Management in its early years, served as president 
of the NE SRM in 1959 and was president of the International Society in 1969.

Don served as a counselor at the first Nebraska Range Youth Camp in 1963 at the State 4-H Camp facility. He attended Range Camp for many years. He was instrumental in organizing and participated in many range-judging contests over the years. He furnished grass weavings for the annual auction to fund activities for SRM youth, established a scholarship to help SRM Youth Forum members attend the International meetings, and helped form the Student Conclave in 1970.

Don received the Nebraska Range Management Award in 1966, the International Fellow Award in 1977, and the Nebraska Section Special Award in 1992.

Don's children, Marvin and his wife, Linda, and Beverly French, along with numerous grandchildren and great-grandchildren, nieces, nephews, and friends were in attendance for the tour and the memorial dedication. Several participants were overheard saying that Don Cox would have enjoyed both teaching and learning at the tour.

Authors are Judy Lanka, Correspondent, The North Platte Telegraph; Michael Croxen, Rangeland Management Specialist, USDA Forest Service, Bessey Ranger District; Patti Barney, District Manager, USDA Forest Service, Bessey Ranger District; Mary Reece, District Conservationist, USDA Natural Resources Conservation Service; Kristin Miller, District Conservationist, USDA National Resource Conservation Service; and Tim Griffin, Rangeland Management Specialist, USDA Forest Service, Bessey Ranger District.

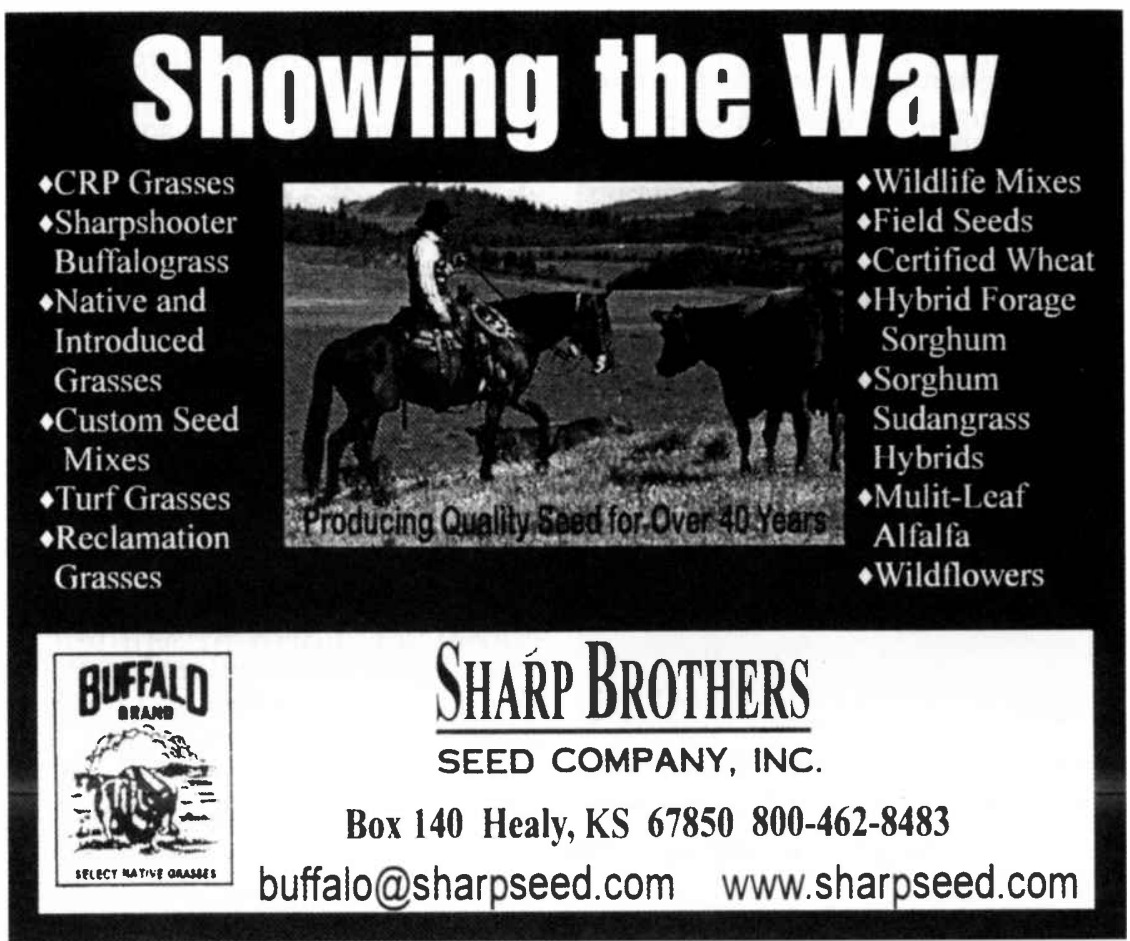

